Winter 2015

\title{
Immigrant Lawyers and the Changing Face of the U.S. Legal Profession
}

\author{
Ethan Michelson \\ Indiana University Maurer School of Law, emichels@indiana.edu
}

Follow this and additional works at: https://www.repository.law.indiana.edu/ijgls

Part of the International Law Commons, Legal Education Commons, and the Legal Profession Commons

\section{Recommended Citation}

Michelson, Ethan (2015) "Immigrant Lawyers and the Changing Face of the U.S. Legal Profession," Indiana Journal of Global Legal Studies: Vol. 22 : Iss. 1 , Article 6.

Available at: https://www.repository.law.indiana.edu/ijgls/vol22/iss1/6

This Article is brought to you for free and open access by the Law School Journals at Digital Repository @ Maurer Law. It has been accepted for inclusion in Indiana Journal of Global Legal Studies by an authorized editor of Digital Repository @ Maurer Law. For more information, please contactrvaughan@indiana.edu.

\section{$\Psi$}

JEROME HALL LAW LIBRARY

INDIANA UNIVERSITY

Maurer School of Law
Bloomington 


\title{
Immigrant Lawyers and the Changing Face of the U.S. Legal Profession
}

\author{
ETHAN MICHELSON*
}

Lazarus-Black and Globokar examine the work both of foreign applicants to two LL.M. programs and of the law school administrators and faculty who decide "Who's In [and] Who's Out."1 The LL.M. admissions process is an increasingly important determinant of the overall volume and composition of law school enrollments. At stake are the futures not only of individual applicants, but also of law schools. In this Comment, I extend Lazarus-Black and Globokar's analysis further downstream to consider the stakes for the U.S. legal profession as a whole. Gatekeepers to LL.M. programs are doing far more than determining individual fates and collectively shaping the future of U.S. legal education. I will demonstrate in this Comment that their work helps shape-in concrete, measurable ways-the demographic composition of the U.S. legal profession. In so doing, I will contribute to the emerging field of legal demography, which refers to the study of lawyers through the analysis of data not collected for this specific purpose. ${ }^{2}$

Carole Silver portrays LL.M. programs as engines propelling the global diffusion of legal practice in all directions. ${ }^{3}$ LL.M. graduates use

* Associate Professor of Sociology and Law, Indiana University-Bloomington. I am grateful to Carole Silver for help and guidance with this and related research projects.

1. Mindie Lazarus-Black \& Julie Globokar, Foreign Attorneys in U.S. LL.M. Programs: Who's In, Who's Out, and Who They Are, 22 InD. J. GLOBAL LEGAL STUD. 1, 1 (2015).

2. For an example of legal demography, see generally Ethan Michelson, Women in the Legal Profession, 1970-2010: A Study of the Global Supply of Lawyers, 20 IND. J. GLOBAL LEGAL STUD. 1071 (2013) (measuring the changing global composition of lawyers in general and female lawyers in particular).

3. See generally Carole Silver, The Case of the Foreign Lawyer: Internationalizing the U.S. Legal Profession, 25 FORDHAM INT'L L.J. 1039 (2002) (analyzing the experience of LL.M. graduates, and how law firms have used foreign lawyers to expand into the international field); Carole Silver, Internationalizing U.S. Legal Education: A Report on the Education of Transnational Lawyers, 14 CARDOzo J. INT'L \& COMP. L. 143 (2006) (examining the growth of U.S. LL.M. programs and their impact on the transnational legal market); Carole Silver, States Side Story: Career Paths of International LL.M.

Indiana Journal of Global Legal Studies Vol. 22 \#1 (Winter 2015)

(C) Indiana University Maurer School of Law 
their unique boundary-spanning legal, cultural, and linguistic skills to serve as international legal interlocutors. Whether they return to their home countries or stay in the United States, LL.M. graduates serve as "agents of globalization in law." 4 My goal in this Comment is to show that immigrant lawyers, many of whom earned LL.M. degrees, are also agents of gender, racial, and ethnic diversity. As we will see, they are literally and figuratively changing the face of the U.S. legal profession.

Silver estimates an annual enrollment of at least 4,000 foreign students in U.S. LL.M. programs. ${ }^{5}$ She also estimates that about 18 percent of foreign LL.M. students stay in the United States after graduating. ${ }^{6}$ Combining these two estimates implies that approximately 720 immigrants enter the U.S. legal profession each year via LL.M. programs (which feed into JD programs and allow students to take the New York and California bar examinations). To be sure, LL.M. programs are not the only gateway into the U.S. legal profession. Because the data I analyze contain no information about U.S. legal education, my analytical scrutiny in this Comment extends to all foreign-born lawyers, whom I define as practicing lawyers who were born outside of the United States. I also analyze a subset of these foreign-born lawyers: adult-immigrant lawyers, whom I define as practicing lawyers who first entered the United States at the age of twenty-two or older. Although LL.M. recipients undoubtedly account for a sizeable proportion of the immigrant lawyers I analyzed, I am unable to estimate the mix of JD, LL.M., and other degree holders in this population. ${ }^{7}$

Data from the decennial census "long form" and the American Community Survey (ACS) contain information on over 100,000 lawyers

Students, or "I Like to Be in America", 80 FoRDHAM L. REV. 2383 (2012) [hereinafter States Side Story] (studying the career paths of international law graduates who earned an LL.M. in the U.S.).

4. Carole Silver, Agents of Globalization in Law: Phase 1, in LSAC RESEARCH REPORT SERIES, at 1 (Law School Admissions Council Grants Report 09-01, 2009), available at http://www.lsac.org/docs/default-source/research-\%28lsac-resources\%29/gr-09-01.pdf?sfvrsn=2 [hereinafter Agents of Globalization in Law].

5. See id. at 2-3. This is a rough estimate given the absence of any comprehensive data on LL.M. students.

6. States Side Story, supra note 3, at 2396.

7. Silver estimates that $77 \%$ of foreign LL.M. graduates who stayed in the United States have been admitted to a state bar. E-mail from Carole Silver, Professor of Global Law \& Practice, Nw. Univ. Law Sch., to Ethan Michelson, Associate Professor of Sociology and Law, Ind. Univ. (Oct. 29, 2014) (discussing Silver's survey, collected with funding from the Law School Council, of 360 foreign students who graduated in 1996, 1998, and 2000 from eleven LL.M. programs). For additional findings from this survey, see Agents of Globalization in Law, supra note 4; States Side Story, supra note 3. 
in the thirteen years spanning 2000-2012.8 These data were collected from nationally representative samples of the total U.S. population: $5 \%$ in $2000,0.43 \%$ in $2001,0.38 \%$ in $2002,0.42 \%$ in 2003 and 2004 , and $1 \%$ annually between 2005 and 2012 . The data contain occupational codes sufficiently detailed to identify "lawyers, and judges, magistrates, and other judicial workers." To exclude nonpracticing lawyers and nonlawyers from this category, I limit the scope of the analysis to individuals who were employed and working in the "legal services" industry. Altogether, across all samples in this thirteen-year period, 103,167 individuals fit this definition of "lawyer." Since each annual sample was constructed independently, we have no way of knowing how many, if any, of these individuals were surveyed more than once. Applying population weights, these 103,167 lawyers represent an estimated average annual population of 695,024 over the 2000-2012 time period.

Unless foreign-born and adult-immigrant lawyers are predominantly white European men, or unless they are exceedingly few in number, they are, by definition, serving to diversify the demographic composition of the U.S. legal profession. In their article, Lazarus-Black and Globokar present data and summarize previous research findings that show a sizeable share and growing prominence of underrepresented minorities in LL.M. programs. Indeed, we know that the population of U.S. lawyers has become increasingly diverse over time in terms of gender, race, and ethnicity..$^{9}$ Immigrant lawyers are fueling this process of demographic change in the U.S. legal profession. Although this assertion is self-evident (even tautological), no previous effort has been made to measure the impact of immigrant lawyers on the demographic composition of the U.S. legal profession.

The estimated average annual population of 695,024 lawyers in the data is considerably smaller than the American Bar Association (ABA) estimates of licensed lawyers, which have exceeded one million per year since 1999.10 This discrepancy stems, in part, from the restrictive

8. Minn. Population Ctr., Univ. of Minn., Integrated Public Use Microdata SERIES: VERSION 5.0 (2010), https:/usa.ipums.org/usa.

9. On women, see Fiona Kay \& Elizabeth Gorman, Women in the Legal Profession, 4 ANN. REV. L. \& SOC. SCI. 299, 300 (2008); Michelson, supra note 2, at 1074. On race and ethnicity, see Ryan D. King et al., Demography of the Legal Profession and Racial Disparities in Sentencing, 44 LAW \& Soc'Y REV. 1, 1 (2010); Lawyer Demographics, AM. BAR ASS'N (2013), http://www.americanbar.org/content/dam/aba/administrative/market research/lawyer_demographics_2013.pdf.

10. Total National Lawyer Counts 1878-2013, AM. BAR ASS'N (2013), http://www.americanbar.org/content/dam/aba/administrative/market_research/total_natio nal_lawyer_counts_1878_2013.authcheckdam.pdf; Lawyer Demographics, supra note 9. 
definition used in my analysis, and also from the overly inclusive nature of the ABA estimates, which include all members of all state bars regardless of whether or not they are employed as lawyers, and may even double-count lawyers who have been admitted to more than one state bar.

Table 1 shows change over time in census and ACS estimates of the size of the U.S. legal profession disaggregated by immigrant status. Between 2000 and 2012, the population of all lawyers grew by $12.5 \%$, and the annual growth (year-on-year change) averaged 1.1\%. Growth estimates are even smaller among U.S.-born lawyers. Growth estimates for immigrant lawyers, however, are dramatically greater. Indeed, the population of adult-immigrant lawyers almost doubled in this time period. Although the population of immigrant lawyers is only a tiny fraction of all lawyers (an average of 7\%), it accounts for approximately one quarter of total lawyer population growth between 2000 and 2012.

Table 1. Population Estimates of Lawyers by Immigrant Status, 20002012

\begin{tabular}{lcccc}
\hline \hline Year & All Lawyers & $\begin{array}{c}\text { U.S. } \\
\text {-Born }\end{array}$ & $\begin{array}{c}\text { Foreign } \\
\text {-Born }\end{array}$ & $\begin{array}{c}\text { Adult } \\
\text { Immigrants }\end{array}$ \\
\hline 2000 & 664,066 & 627,210 & 36,856 & 11,184 \\
2001 & 640,991 & 602,538 & 38,453 & 13,839 \\
2002 & 632,134 & 598,769 & 33,365 & 11,259 \\
2003 & 657,026 & 611,080 & 45,946 & 13,495 \\
2004 & 708,378 & 661,739 & 46,639 & 14,985 \\
2005 & 685,592 & 642,300 & 43,292 & 14,202 \\
2006 & 694,059 & 651,220 & 42,839 & 12,824 \\
2007 & 719,804 & 670,292 & 49,512 & 15,558 \\
2008 & 731,254 & 676,798 & 54,456 & 20,319 \\
2009 & 736,313 & 683,591 & 52,722 & 15,379 \\
2010 & 701,514 & 647,929 & 53,585 & 15,271 \\
2011 & 716,847 & 664,813 & 52,034 & 13,107 \\
2012 & 747,332 & 688,434 & 58,898 & 20,022 \\
Total & $12.5 \%$ & $9.8 \%$ & $59.8 \%$ & $79.0 \%$ \\
growth & & & & \\
Average & $1.1 \%$ & $0.8 \%$ & $4.7 \%$ & $7.2 \%$ \\
growth & & & & \\
\hline
\end{tabular}

Note: "Foreign-born" and "adult immigrants" are not mutually exclusive categories.

The data also reveal that immigrant lawyers have a disproportionate share (relative to U.S.-born lawyers) of women and racial and ethnic minorities. Table 2 contains census and ACS estimates 
of the gender composition of immigrant lawyers. The overall estimate of $27.8 \%$ women is within the range of $A B A$ estimates of $27 \%$ in 2000 and of $30 \%$ in 2005.11 Table 2 also shows that the proportion of women in the immigrant lawyer population far exceeds the proportion of women in the U.S.-born lawyer population (by between $33 \%$ and $44 \%$ ). Insofar as newer and younger cohorts of lawyers have higher percentages of women, and insofar as immigrant lawyers tend to be younger than U.S.born lawyers, one might reasonably hypothesize that these differences can be attributed to differences between U.S.-born and immigrant lawyers in timing of entry into the legal practice. Nevertheless, multivariate regression models that control for survey year and lawyer age fail to support this hypothesis. Among lawyers of the same age observed in the same year, immigrant lawyers are between $32 \%$ and $41 \%$ more likely than U.S.-born lawyers to be women. ${ }^{12}$ The data clearly show the substantial contribution of immigrant lawyers to the feminization of the U.S. legal profession.

Table 2. Estimates of the Gender Composition of Lawyers by Immigrant Status, 2000-2012

\begin{tabular}{llllc}
\hline \hline & All Lawyers & U.S.-Born & Foreign-Born & $\begin{array}{c}\text { Adult } \\
\text { Immigrants }\end{array}$ \\
\hline Female & $27.8 \%$ & $27.0 \%$ & $39.0 \%$ & $36.3 \%$ \\
Male & $72.2 \%$ & $73.0 \%$ & $61.0 \%$ & $63.7 \%$ \\
Total & $100.0 \%$ & $100.0 \%$ & $100.0 \%$ & $100.0 \%$ \\
N & $9,035,310$ & $8,426,713$ & 608,597 & 191,444 \\
\hline
\end{tabular}

Note: To estimate the average annual population during this time period, divide $\mathrm{Ns}$ by 13 .

The impact of immigrant lawyers on the racial and ethnic composition of the U.S. legal profession is even more dramatic. In the time period from 2000 to $2012,23.1 \%$ of all adult-immigrant lawyers were born in China (8.9\%), India (7.6\%), Korea $(5.0 \%)$, and Japan (1.6\%). China's share of adult-immigrant lawyers noticeably increased over this time period from $7.1 \%$ in the $2000-2007$ period to $11.2 \%$ in the 2008-2012 period. Indeed, in terms of the rankings of all fifty-nine birthplace categories according to the size of their contributions to the adult-immigrant lawyer population in the United States, China climbed from an average ranking of fifth in the 2000-2007 period to an average ranking of second in the 2008-2012 period, and ultimately to the first

11. Lawyer Demographics, supra note 9.

12. These differences are highly statistically significant. Detailed regression results are omitted owing to space constraints. 
ranking in 2012 (supplying an estimated 2,726 adult-immigrant lawyers observed in the U.S. legal profession in that year). South American and African countries are also major contributors to the population of adultimmigrant lawyers, accounting for $7.3 \%$ and $8.1 \%$ respectively. Disaggregating the categories of "South America" and "Africa" is possible by using information about family ancestry and country of residence in the previous year. The greatest South American contributors appear to be Brazil and Colombia, and the greatest African contributors are Nigeria, Egypt, and South Africa.

Given what we now know about their birthplaces, we should not be surprised by the disproportionately high representation of Asians, Hispanics, and blacks among immigrant lawyers. Table 3 brings into high relief the contributions of immigrant lawyers to ethnic and racial diversity in the U.S. legal profession as a whole. The overall racial and ethnic composition of lawyers in Table 3 roughly mirrors 2010 ABA figures of $3.5 \%$ for "Asian Pacific American, not Hispanic"; $3.7 \%$ "Hispanic"; 4.8\% "Black, not Hispanic"; and 88.1\% "White, not Hispanic." 13 We can see that the proportion of Asians in the immigrant lawyer population far exceeds the proportion of Asians in the U.S.-born lawyer population (by a factor of fifteen). Likewise, the proportions of Hispanics and blacks respectively in the immigrant lawyer population far exceed those in the U.S.-born lawyer population (by factors of three to four). In terms of absolute numbers, Hispanics and blacks have respectively contributed approximately 1,500 adult immigrants to the U.S. legal profession per year (for a combined total exceeding 3,000 each year). Finally, adult-immigrant Asians in the U.S. legal profession are both more numerous and growing faster than their Hispanic and black counterparts.

13. Lawyer Demographics, supra note 9. 
Table 3. Estimates of the Racial/Ethnic Composition of Lawyers by Immigrant Status, 2000-2012

\begin{tabular}{lcclc}
\hline \hline & All Lawyers & U.S.-Born & $\begin{array}{l}\text { Foreign- } \\
\text { Born }\end{array}$ & $\begin{array}{c}\text { Adult } \\
\text { Immigrants }\end{array}$ \\
\hline Asian & $3.5 \%$ & $1.8 \%$ & $26.8 \%$ & $28.7 \%$ \\
Hispanic & $4.0 \%$ & $3.3 \%$ & $13.9 \%$ & $11.2 \%$ \\
Black & $3.6 \%$ & $3.2 \%$ & $8.3 \%$ & $9.8 \%$ \\
Other & $89.1 \%$ & $91.8 \%$ & $51.6 \%$ & $50.5 \%$ \\
Total & $100.2 \%$ & $100.2 \%$ & $100.6 \%$ & $100.2 \%$ \\
N & $9,035,310$ & $8,426,713$ & 608,597 & 191,444 \\
\hline
\end{tabular}

Note: Since survey respondents are permitted to report multiple races/ethnicities (e.g., black Hispanic), some (very few) people included in this table are double counted. For this reason totals exceed $100.0 \%$. To estimate the average annual population during this time period, divide Ns by 13 .

In summary, the face of the U.S. legal profession would appear quite different without immigrants. Law schools help drive immigration, which in turn helps drive gender, racial, and ethnic diversification in the U.S. legal profession. Although some of the immigrant lawyers included in this analysis never earned LL.M. degrees, many surely did. Because it is of enormous consequence to the demographic composition of the U.S. legal profession, the work of gatekeepers to LL.M. programs merits careful study in precisely the way Lazarus-Black and Globokar do in their article, featured in this special issue of the Indiana Journal of Global Legal Studies.

This Comment represents a first step toward a more thorough assessment of the impact of immigrant lawyers on the demographic composition of the U.S. legal profession. Next steps should include an assessment of their impact on the geographical distribution of the U.S. legal profession. Future research should also expand the scope of analysis to assess the impact of immigrant lawyers on other segments of the U.S. legal profession. I have shown that they are changing the face of the largest segment of the U.S. legal profession, namely the "legal services" industry. Future research will tell us the extent to which they are changing the face of the U.S. legal profession in other work settings, including universities and business organizations. 